\section{ABCS}

How to cite this article: Sena et al. The effect of replacing sedentary behavior by different intensities of physical activity in body composition: a systematic review. ABCS Health Sci. 2021;46:e021305. https://doi. org/10.7322/abcshs.2020145.1594

Received: Oct 06, 2020

Revised: Feb 22, 2021

Approved: Mar 12, 2021

Corresponding author: Éricka Janine Dantas da Silveira - Universidade Federal do Rio Grande do Norte, Departamento de Odontologia - Avenida Senador Salgado Filho, 1787, Lagoa Nova - CEP: 59056-000 - Natal (RN), Brasil - E-mail: ericka_janine@ yahoo.com.br

Funding: UFRN and CAPES. LPP e LBS are recipients of fellowship from $\mathrm{CNPq}$.

This is an open access article distributed under the terms of the Creative Commons Attribution License.

(C) 2021 The authors

\title{
COVID-19 in dental practice - An overview of challenges and preventive measures
}

\author{
Dáurea Adília Cóbe Sena1, Caio César da Silva Barros ${ }^{1}$, Larissa Santos Amaral Rolim¹, \\ Leão Pereira Pinto1, Lélia Batista de Souza1, Éricka Janine Dantas da Silveira1 \\ ${ }^{1}$ Programa de Pós-Graduação em Ciências Odontológicas, Universidade Federal do Rio Grande do \\ Norte (UFRN) - Natal (RN), Brazil
}

\begin{abstract}
COVID-19 was identified to be caused by a new coronavirus named as SARS-CoV-2. Since the outbreak of this disease, World Health Organization (WHO) declared a global public health emergency. SARS-CoV-2 has a high estimate rate of human-tohuman transmission mainly through inhalation/ingestion/direct mucous contact with respiratory droplets. Considering this high transmission capacity, several countries have already registered cases of infection by health professionals. Even though dentists are not directly involved in the diagnosis and therapy of COVID-19 they represent undoubtedly a risk group due to high exposure and their work environment is a contagion factor for patients and staff. In this manner, the objective of this article is to approach important aspects of COVID-19 concerning dental care and provides an overview of its challenges on dental practice. For this, we used these following keywords in our research: COVID-19; dental general practice; prevention and control; infectious disease transmission; infectious disease transmission, patient to professional. Taking into account the global concern with patient care in midst of this pandemic, we address valid concerns regarding the potential means of contamination in the dental office and highlight practices and guidelines adopted in different countries to minimize risks in dental care in this global public health crisis, thus, reinforcing the challenges of dentistry in this context, highlighting the importance of rigorous preventive measures. However, there is still a lack of standardization of dental care protocols and consequently, reduce the risk of contagion.
\end{abstract}

Keywords: Coronavirus; COVID-19; disease prevention; general practice, dental; disease transmission, infectious.

\section{INTRODUCTION}

In December 2019, new viral pneumonia caused by an unknown pathogen was reported at Wuhan, Hubei Province, China. Later, the World Health Organization (WHO) declared this outbreak, called coronavirus disease 2019 (COVID-19), a public health problem of global concern ${ }^{1-3}$. At the time of preparing this article, there are 11,125,245 cases and 528,204 deaths by COVID-19 confirmed worldwide and an increase in the number of new cases is observed in the United States, Brazil, and India ${ }^{4}$.

The pathogen of COVID-19 was identified as a new coronavirus, named severe acute respiratory syndrome coronavirus 2 (SARS-CoV-2). After the severe acute respiratory 
syndrome (SARS) and the Middle East respiratory syndrome (MERS), this is the third coronavirus pandemic of infectious respiratory diseases with high mortality in less than 20 years ${ }^{3,5,6}$. SARS-CoV-2 has a high estimate rate of reproduction and its transmission from human-to-human occurs mainly through inhalation/ingestion/direct mucous contact with respiratory droplets produced when an infected person coughs or sneezes, and this feature makes its control extremely challenging ${ }^{1,2}$.

At onset of COVID-19, the most frequent symptoms include fever, fatigue, myalgia, cough, and acute respiratory disease, which can lead to pneumonia in severe cases $^{7-9}$. Asymptomatic infections apparently can be transmissible before any symptoms rise ${ }^{8}$. Some patients can present pulmonary infiltrates on chest radiography, decrease in lymphocytes, white blood cells and platelet population ${ }^{7,9}$. Besides that, sore throat, hyposmia, hypogeusia, diarrhea, dyspnea, and dermatologic alterations have been reported in some patients with this disease ${ }^{10,11}$. Oral manifestations, as desquamative gingivitis, ulcers, and blisters were reported in three cases (two suspects and one confirmed) ${ }^{10}$.

Initially, in China, health professionals provided emergency care to patients infected by SARS-CoV-2, a small number of these professionals have also become infected, and some died. Although dentists are not directly involved in the diagnosis and therapy of COVID-19, as demonstrated by The New York Times article "The Workers Who Face the Greatest Coronavirus Risk", they are the healthcare professionals with the most risk of exposure and subsequent infection by SARS-CoV-2, when compared to nurses and physicians ${ }^{1,12}$. In this way, this article shows and discusses important aspects of COVID-19 concerning dental care, and provides an overview of its challenges on dental practice.

\section{Transmission}

Coronaviruses are a diverse family of viruses that can be classified as alpha-, beta-, gamma-, and delta-coronavirus. Most infectious diseases in humans caused by Coronavirus, only alpha and beta-CoV mainly infect the respiratory, gastrointestinal and central nervous systems ${ }^{2,13-15}$. It is not yet clear which species of animal was responsible for transmission of the 2019 novel coronavirus (SARS-CoV-2), but it is known that several wild animals such as bats, cats or cattle can serve as hosts ${ }^{7}$. Due to the history of exposure of a large number of infected people to a wild animal market in the city of Wuhan in China, it is believed that the probable origin of the agent came from an animal'.

The SARS-CoV-2 is an enveloped non-segmented positivesense RNA virus, and it was seen that SARS-CoV-2 share similar genome with the genome sequence of bats ( $96.2 \%$ identical) and SARS-CoV (79.5\% identical). Given the similarity of genetic sequences with bats, it is believed that this species could have been the host of the virus's origin, even though the path of the virus through intermediate hosts to humans is not known yet ${ }^{16}$.
Previous studies have shown that SARS-CoV-2 spike glycoproteins promote infection by binding to the angiotensin-converting enzyme 2 (ACE2), a specific functional receptor present on the surface of host cells, thus, ACE2 distribution in human tissues indicates the main routes of infection for SARS-CoV-2 $2^{13,15,17,18}$. It has been reported that these receptors are present in arterial smooth muscle cells, as well as epithelial cells of the endothelium, esophagus, small intestine, renal tubular region, and abundantly throughout the respiratory tract, which provides strong support for infection of SARS-CoV-2 through the airways ${ }^{13,17}$.

Person-to-person transmission has been described in different ways in different settings, such as transmission by contact (through oral, nasal and eye mucous membranes after touching infected surfaces or objects), by remote transmission from infected people (through droplets - typically from saliva that can be expelled oral or nasopharyngeally- carrying the virus spread by sneezing or coughing for example) or by aerosol ${ }^{2,7,8}$. Even though there are no clinical manifestations of the virus in the eyes, it has been observed that eye exposure may be a potential entry for SARS-CoV-2 ${ }^{13}$. It has also been reported that asymptomatic patients who tested positive for the presence of genetic material from the virus, but without symptoms such as fever or cough, are also responsible for the transmission of the pathogen via personto-person contact ${ }^{19}$.

Kampf et al. ${ }^{20}$ reinforce the transmission through touching infected surfaces or objects, since SARS-CoV-2 can remain up to nine days on glass, metal, or plastic surfaces, is a potential source of viral transmission in the healthcare environment. Therefore, contamination of frequent touch surfaces in healthcare settings are a potential source of viral transmission. Aerosols generated during clinical procedures is expected to be the major form of acquisition of infection of the virus, due to the spread of contaminated droplets that mix into the air ${ }^{7,8}$. According to Singhal ${ }^{21}$, transmission to healthcare workers caring for infected patients was described on January 20th, 2020. By early March, it has been reported by the National Health Commission of China that at least 3,300 health workers got the infection, as well as Italy, in which $20 \%$ of health-care professionals have become infected ${ }^{22}$. Ong et al. ${ }^{23}$ conducted a study assessing the probable sites of infections at a center dedicated to treat patients with SARS-CoV-2, and out of three patients' room analyzed before and after de routine cleaning, samples collected before routine cleaning had positive results in 13 of 15 room sites and three of five toilet sites indicating that environment - specially places where contaminated patients are - is a very likely medium of transmission.

The high potential for infection of dental professionals is widely known due to their constant exposure to microorganisms that can infect the respiratory tract and oral cavity ${ }^{13}$. The dentist is in direct contact with saliva, blood, sharp objects, and contaminated by body fluids and aerosols that may contain for example 
SARS-CoV-2, which can remain in the air for a prolonged period of time and may have contact with the oral, conjunctival and nasal mucous membranes. This raises concern, since it is practically impossible to avoid the drops and aerosols produced by the infected patient and spread by high-speed instruments (often accompanied by the use of running water), which are routinely used in the profession and mixed with saliva or blood ${ }^{13}$. Bearing this in mind, it is safe to say that the clinical practice of dentistry represents a high-risk factor for professionals in the field during this pandemic.

$\mathrm{Xu}$ et al. ${ }^{18}$ investigated the oral cavity as a potential route of SARS-CoV-2 infection through the expression and proportion of ACE2 in the oral mucosa cells. These authors find that ACE2 was highly expressed in epithelial cells of the oral cavity, especially in the tongue. Liu et al. ${ }^{24}$ reported a wide expression and distribution of ACE2 throughout the upper respiratory tract, as well as in the epithelial cells that lining ducts of the salivary glands. In this way, saliva may be a major source of virions, especially by asymptomatic people, at the beginning of the infection ${ }^{25}$.

What are the implications of COVID-19 in dental practice?

Due to the transmission routes of COVID-19, healthcare professionals and scientists have been concerned with how to reduce the spread of the SARS-CoV-2 in medical and dental practice. Izzetti et al. ${ }^{26}$ reported that more than 13,000 healthcare professionals were infected by SARS-Cov- 2 in Italy, of these eight dentists died. The article in the New York Times found that, among healthcare professionals, dentists are the most likely of contracting COVID-19 due to direct contact with patient's droplets and aerosols, since they are generated during dental practice and can be deposited in surfaces. In addition to the dentist being able to contract and transmit COVID-19, there is some difficulty in maintaining a sterile environment among patients. Thus, dental practice may constitute a potential vector of transmission ${ }^{12}$.

According to Meng et al. ${ }^{1}$ and Peng et al. ${ }^{13}$, risk of COVID-19 transmission is high in dental practice due to the diffusion of aerosol particles, which also can promote the contamination of instruments and surfaces in the dental environment. In this way, these authors reinforce that the contact with COVID-19 patients, symptomatic or not, undergoing dental procedures represents to the dental staff a potential source of infection.

\section{Prevention of COVID-19 for}

\section{dental healthcare professionals}

Due to the high risk of transmission of infectious diseases in the dental office, it is essential for the staff to effectively follow the recommendations of health agencies. In this context, the WHO highlights the importance of the usage of full personal protective equipment (PPE) such as gown, head cover, gloves, eye protection (goggles or face shield), and surgical mask or respirators (N95, FFP2 or FFP3), as well as frequent hand hygiene ${ }^{27}$.
Although this agency has not prepared a specific guideline for the use of PPE in dental practice, in a similar way, several countries have taken its recommendations concerning PPE, as described in Table 1.

Hand hygiene is another critical measure for reducing SARS-CoV-2 transmission since it is a simple measure, and that can reduce potential pathogens on the hand. According to $\mathrm{WHO}^{27}$, it is important to perform hand hygiene in some situations such as contact with a patient or non-disinfected surfaces or equipment and after disposing of the surgical mask or respirator. In this way, it is necessary to perform hand hygiene constantly with antiseptic agents or soap and water even if hands are not visibly dirty. Besides that, it is recommended to avoid touching eyes, mouth, and nose without an adequate hand hygiene and to ask the patient with symptoms suggestive of COVID-19 to perform hand hygiene ${ }^{26,27}$. However, it is equally important to take some measures in the dental office before, during and after dental care, which should be related to avoiding overcrowding in waiting rooms, screening and recognition of suspected patients as well as routine cleaning and disinfection of the environment.

\section{Patient screening and prevention in the dental office}

In the United States, Centers for Disease Control and Prevention (CDC) and American Dental Association (ADA) have respected the guidance and hygiene guidelines recommended by WHO. Initially, these organizations recommended the suspension of elective procedures for patients with respiratory symptoms, instructing dentists on performing accurate anamnesis and screening. Besides, measures to reduce transmission of COVID-19 must begin before the service, through monitoring of the health staff itself and preparing the dental office to minimize the risk of transmission during dental procedures ${ }^{28,29}$.

Several reports in some countries have been prepared to decrease the transmission of COVID-19. In most of these reports, it is recommended scheduling patients at sparse times, so that there is no agglomeration and allowing sufficient time for the proper cleaning of the environments. Patients should be aware of how to avoid taking companions to the appointment, except in extreme cases (pediatric patients, elderly, or people with disabilities). In addition, in a waiting room, all objects that can be touched by several people (magazines and toys) must be removed, and the need to signalize signs and symptoms of the coronavirus and preventive measures should be emphasized ${ }^{26,29-31}$ (Table 1).

In Italy, the Società Italiana di Parodontologia e Implantologia (SIdP) together with Comitato Italiano di Coordinamento delle Società Scientifiche Odontostomatologiche (CIC Odontoiatria) regulated dental activities during the pandemic with measures adopted by the local Ministry of Health. These organizations mainly specify hygiene and disinfection measures in the preoperative 
Table 1: Recommendations concerning the use of PPE, activity, and routine cleaning and disinfection in the dental office.

\begin{tabular}{|c|c|c|c|c|}
\hline Measures & China (NHC) & $\begin{array}{c}\text { United States (ADA } \\
\text { and CDC) }\end{array}$ & $\begin{array}{l}\text { Italy (SIdP and } \\
\text { CICOdontoiatria) }\end{array}$ & Brazil (ANVISA and CFO) \\
\hline $\begin{array}{l}\text { Personal } \\
\text { Protective } \\
\text { Equipment } \\
\text { (PPE) }\end{array}$ & $\begin{array}{l}\text { White coat, disposable } \\
\text { protective clothing, head } \\
\text { cover, surgical mask, } \\
\text { protecting goggles or } \\
\text { face shield, disposable } \\
\text { gloves, and impermeable } \\
\text { shoe cover; } \\
\text { There is no mention of } \\
\text { N95/PPF2 respirator. }\end{array}$ & $\begin{array}{l}\text { - General work clothes, } \\
\text { disposable protective } \\
\text { clothing (gowns), } \\
\text { head cover, surgical } \\
\text { mask, face shield, and } \\
\text { disposable gloves; } \\
\text { - Preference for using the } \\
\text { N95/PFF2 respirator. }\end{array}$ & $\begin{array}{l}\text { Disposable protective clothing, } \\
\text { head cover, surgical mask } \\
\text { (change to each patient } \\
\text { using gloves to remove), } \\
\text { protecting goggles, face } \\
\text { shield, disposable gloves, and } \\
\text { impermeable shoe cover; } \\
\text { - Use PFF 2-3 respirator } \\
\text { when possible. }\end{array}$ & $\begin{array}{l}\text { - General work clothes, } \\
\text { disposable impermeable } \\
\text { protective clothing } \\
\text { (gowns), head cover, } \\
\text { surgical mask, protecting } \\
\text { goggles, face shield, } \\
\text { and disposable gloves; } \\
\text { - Preference for using the } \\
\text { N95/PFF2 respirator. }\end{array}$ \\
\hline Pre-service & $\begin{array}{l}\text { - Screening to identify } \\
\text { suspected patients; } \\
\text { - Check body temperature; } \\
\text { - Use of surgical masks } \\
\text { by patients; } \\
\text { - Disinfection of tables, } \\
\text { chairs, handles, elevators; } \\
\text { - Avoid direct contact } \\
\text { with elevator buttons; } \\
\text { - Disinfection of all surfaces } \\
\text { of dental office; } \\
\text { - Hand hygiene of health } \\
\text { professionals; } \\
\text { - Schedule procedures with } \\
\text { the use of a high-speed } \\
\text { drill for the end of the day. }\end{array}$ & $\begin{array}{l}\text { - Staff vaccinated } \\
\text { against influenza; } \\
\text { - Removal of professionals } \\
\text { with symptoms or } \\
\text { at risk group; } \\
\text { - Inform the local } \\
\text { health department of } \\
\text { suspected patients; } \\
\text { - Screening via call center } \\
\text { and at office (patients } \\
\text { and companions); } \\
\text { - Spaced patient schedules; } \\
\text { - Advise on companions } \\
\text { (only if necessary); } \\
\text { - Removing objects from } \\
\text { the waiting room; } \\
\text { - Keep } 2 \text { meters away } \\
\text { from people. }\end{array}$ & $\begin{array}{l}\text { - Telephone and in- } \\
\text { office screening; } \\
\text { - Leave belongings in } \\
\text { the waiting room; } \\
\text { - Check body temperature; } \\
\text { - Store electronic devices; } \\
\text { - Use of disposable } \\
\text { sneakers by patients; } \\
\text { - Keep distance of } 1 \text { meter; } \\
\text { - Hand hygiene (patients); } \\
\text { - Disinfection and protection } \\
\text { of electronic devices } \\
\text { and office equipment; } \\
\text { - Place on the benches only } \\
\text { the material to be used; }\end{array}$ & $\begin{array}{l}\text { - Telephone screening; } \\
\text { - Spaced patient } \\
\text { appointments ( } 20 \text { min); } \\
\text { - Check body temperature; } \\
\text { - Guide the hygiene of the } \\
\text { patient's hands and face } \\
\text { and use of a mask and } \\
\text { gloves in the waiting room; } \\
\text { - Maintenance of } 2 \text { meters } \\
\text { between receptionist } \\
\text { and patient; } \\
\text { - Cleaning the environment } \\
\text { with } 1 \% \text { sodium } \\
\text { hypochlorite or lysoform; } \\
\text { - Place protective barriers } \\
\text { in equipment and } \\
\text { perform disinfection } \\
\text { with } 70 \% \text { alcohol. }\end{array}$ \\
\hline $\begin{array}{l}\text { During } \\
\text { service }\end{array}$ & $\begin{array}{l}\text { - Adoption of emergency } \\
\text { treatment; } \\
\text { - Initial mouthwash (30s) with } \\
1 \% \text { hydrogen peroxide; } \\
\text { - Avoid using a triple syringe; } \\
\text { - Use of rubber dam isolation } \\
\text { and effective suction; } \\
\text { - Use of chemicals to remove } \\
\text { caries and minimize the } \\
\text { use of handpieces; } \\
\text { - Avoid intraoral radiographs; } \\
\text { - Use rooms with } \\
\text { good ventilation or } \\
\text { negative pressure for } \\
\text { suspected patients; } \\
\text { - Use absorbable sutures; } \\
\text { - Refer life-threatening } \\
\text { patients to hospitals. }\end{array}$ & $\begin{array}{l}\text { - Adoption of urgent and } \\
\text { emergency treatment; } \\
\text { - Initial mouthwash with } \\
1 \% \text { hydrogen peroxide or } \\
0.2 \% \text { povidone iodine; } \\
\text { - Decrease aerosol- } \\
\text { generating procedures; } \\
\text { - Avoid using the } \\
\text { triple syringe; } \\
\text { - Use of rubber dam isolation; } \\
\text { - Opt for extraoral } \\
\text { radiographs; } \\
\text { - Use handpieces with } \\
\text { anti-retract function and } \\
\text { high volume evacuators; } \\
\text { - Use absorbable sutures; } \\
\text { - Schedule aerosol- } \\
\text { generating procedures } \\
\text { for the end of the day. }\end{array}$ & $\begin{array}{l}\text { - Adoption of urgent and } \\
\text { emergency treatment; } \\
\text { - Limit service time } \\
\text { to } 15 \text { minutes; } \\
\text { - Initial mouthwash (30s) } \\
\text { with } 1 \% \text { hydrogen peroxide } \\
\text { or } 0.2 \% \text { povidone iodine } \\
\text { - Use of rubber dam isolation; } \\
\text { - Avoid the use of ultrasound } \\
\text { and devices that generate } \\
\text { aerosols (limit the use } \\
\text { of handpieces); } \\
\text { - Keep doors closed } \\
\text { during service. }\end{array}$ & $\begin{array}{l}\text { - Adoption of urgent and } \\
\text { emergency treatment; } \\
\text { - Appointments with closed } \\
\text { doors and open windows; } \\
\text { - Initial mouthwash } \\
\text { with } 1 \% \text { hydrogen; } \\
\text { - Use of rubber dam isolation; } \\
\text { - Decreased aerosol- } \\
\text { generating procedures and } \\
\text { the use of a triple syringe, } \\
\text { ultrasound device and } \\
\text { high and low rotation drill; } \\
\text { - Prefer chemomechanical } \\
\text { procedures for the removal } \\
\text { of caries and pulp exposure; } \\
\text { - Use absorbable sutures; } \\
\text { - Refer life-threatening } \\
\text { patients to hospitals. }\end{array}$ \\
\hline Aftercare & $\begin{array}{l}\text { - The waste generated } \\
\text { must be disposed of } \\
\text { in a timely manner; } \\
\text { - The waste coming from } \\
\text { patients with suspected } \\
\text { or confirmed COVID-19 } \\
\text { should be stored in well } \\
\text { identified packaging; } \\
\text { - Instruments and } \\
\text { reusable items must } \\
\text { be cleaned, sterilized } \\
\text { and stored properly. }\end{array}$ & $\begin{array}{l}\text { - Clean and disinfect } \\
\text { reusable PPE and non- } \\
\text { disposable equipment; } \\
\text { - Handpiece cleaning, } \\
\text { disinfection and sterilization; } \\
\text { - Disinfect all surfaces that } \\
\text { can be touched inside } \\
\text { and outside office. }\end{array}$ & $\begin{array}{l}\text { - Removing plastic film and } \\
\text { disinfecting equipment } \\
\text { - Disinfection of all surfaces that } \\
\text { can be touched by patients; } \\
\text { - Clean non-disposable } \\
\text { PPE with } 70 \% \text { alcohol; } \\
\text { - Allow room ventilation } \\
\text { for at least } 5 \text { minutes; } \\
\text { - Hand washing of professionals } \\
\text { for at least } 60 \text { s and } \\
\text { use of } 70 \% \text { alcohol; } \\
\text { - All disposable materials must } \\
\text { be treated as potentially } \\
\text { infectious waste. }\end{array}$ & $\begin{array}{l}\text { - Hand washing of } \\
\text { professionals; } \\
\text { - Allow natural ventilation } \\
\text { of the environment; } \\
\text { - Cleaning the floor } \\
\text { with } 0.1 \% \text { sodium } \\
\text { hypochlorite or lysoform; } \\
\text { - Clean and disinfect all } \\
\text { surfaces inside and outside } \\
\text { the office with neutral } \\
\text { detergent and } 70 \% \text { alcohol; } \\
\text { - Cleaning and sterilization of } \\
\text { hand and instrument parts; } \\
\text { - Cleaning the suction } \\
\text { hoses with chlorine- } \\
\text { based solution. }\end{array}$ \\
\hline
\end{tabular}

environment, since these consist in considerable changes in relation to what was possibly done before the pandemic, in addition to being a place with potential for transmission of COVID-19 (Table 1) ${ }^{32-34}$.

The Agência Nacional de Vigilância Sanitária (ANVISA), a Brazilian health agency, as well as the National Health Commission of the People's Republic of China, has been advising to conduct a pre-service assessment in a similar way ${ }^{13,35}$. According to Arther et al. ${ }^{36}$, initial screening questions, such as presence or absence of symptoms and whether there has been a recent trip to epidemic places, can be done via online call. When identifying suspicious 
patients who need urgent care, they must be in isolated places, with good ventilation and must be instructed in the use of surgical masks and the cough etiquette. It is worth mentioning that these patients should be seen in specialized centers (not in a common dental setting), in rooms with negative pressure. The dentist should encourage them to keep quarantine and see the doctor after the period to confirm the infection ${ }^{36}$.

Peng et al. ${ }^{13}$ report and reinforce the contagion pathways in the dental office and the guidelines adopted in China to reduce COVID-19 in this environment. Most of the parameters reported by Peng et al. ${ }^{13}$ are similar to those adopted by ADA. However, there are occasional differences, and the dentist can also collaborate in the identification of the patients with COVID-19. Thus, the dentist should avoid contact with patients with respiratory diseases and restrict the care of patients who do not exhibit symptoms whose body temperature is below $37.3^{\circ} \mathrm{C}$, while patients with high fever should be referred to hospitals ${ }^{1,13}$.

Concerning dental procedures, it is recommended to postpone routine or non-urgent dental procedures and to perform only when considered as a urgency or emergency ${ }^{29}$. The first ADA report for COVID-19 in March 16, 2020, advised professionals to restrict care to situations that represented life-threatening situations, however, in its most recent protocol in April 1, 2020, this agency highlighted that emergency procedures should also be included in dental care performed during the pandemic. The ADA recommends that dentists use their professional judgment to determine the need for urgent or emergency care according to the situations ${ }^{37}$ described in Table 2. ADA also advised that in case of urgent or emergency dental procedure in a patient suspected of having respiratory disease, dental care should be taken in conjunction with a physician, and also, it was necessary to evaluate if the dental office was appropriate for performing the procedure. According to the ADA guidelines, Figure 1 shows an algorithm to determine the location of where the urgency or emergency dental procedure should be performed ${ }^{38}$.

Meng et al. ${ }^{1}$ reinforce the performance of emergency procedures only in the cities of China. These authors report that even though the National Health Commission of China emphasizes this conduct, the School and Hospital of Stomatology of Wuhan University continued to perform elective care between January and February. In this way, although all preventive care regarding disinfection and technical procedures has been performed, this conduct promotes a high flow and agglomeration of patients, which includes possible asymptomatic patients. Recently, the Ministry of Education of China ordered the suspension of classes at the University until further notice.

In the dental office, procedures that generate aerosols should be avoided or minimized as much as possible. For this purpose, the constant suction of saliva and the use of rubber dam and conventional dentinal curettes are recommended for the removal of caries instead of high or low-speed drills. Intraoral radiographs should be avoided since they stimulate salivation and cough, as well as the use of the spray of the triple syringe, which increases aerosols in the environment. Handpieces with anti-retraction function should be preferable, as it reduces cross infection ${ }^{1,26,29-31,35}$.

Among patients, all reusable PPEs should be washed with soap and water and disinfected. Cleaning and disinfection, previously restricted to the dental chair, handpieces and X-ray devices, must now be performed on the entire clinical environment and common areas ${ }^{1,26,29-31,35}$. The way that each guideline approaches

Table 2: Dental situations that consist in urgent and emergency care (ADA, 2020).

\begin{tabular}{|c|c|c|}
\hline Dental emergencies & Urgent dental care & Routine or non-urgent dental procedures \\
\hline $\begin{array}{l}\text { - Uncontrolled bleeding } \\
\text { - Cellulitis or diffuse soft } \\
\text { tissue bacterial infection } \\
\text { with intra or extraoral } \\
\text { swelling that compromise } \\
\text { the patient's airway } \\
\text { - Trauma involving facial } \\
\text { bones that compromising } \\
\text { the patient's airway }\end{array}$ & $\begin{array}{l}\text { - Severe dental pain from pulpal inflammation } \\
\text { - Pericoronitis or third-molar pain } \\
\text { - Surgical post-operative osteitis, dry } \\
\text { socket dressing changes } \\
\text { - Dental or periodontal abscess or localized bacterial } \\
\text { infection resulting in localized pain and swelling } \\
\text { - Tooth fracture resulting in pain or soft tissue trauma } \\
\text { - Dental trauma with avulsion/luxation } \\
\text { - Dental treatment required prior to } \\
\text { - critical medical procedures } \\
\text { - temal crown/bridge cementation if the } \\
\text { - or resulting in gingival irritation } \\
\text { - Biopsy } \\
\text { - Extensive dental caries or defective } \\
\text { - Suture removal } \\
\text { - Denture adjustment on radiation/oncology } \\
\text { - Ratients or repairs when function impeded } \\
\text { - } \text { openlacing temporary filling on endo access } \\
\text { Snipping or adjustment of an orthodontic } \\
\text { wire ulcerating the oral mucosa }\end{array}$ & $\begin{array}{l}\text { - Initial or periodic oral examinations and } \\
\text { recall visits, including routine radiographs } \\
\text { - Routine dental cleaning and preventive therapies } \\
\text { - Orthodontic procedures other than those to } \\
\text { address acute issues (e.g. pain, infection, trauma) } \\
\text { - Extraction of asymptomatic teeth } \\
\text { - Restorative dentistry including treatment } \\
\text { - } \text { of asymptomatic carious lesions } \\
\text { - Aesthetic dental procedures }\end{array}$ \\
\hline
\end{tabular}




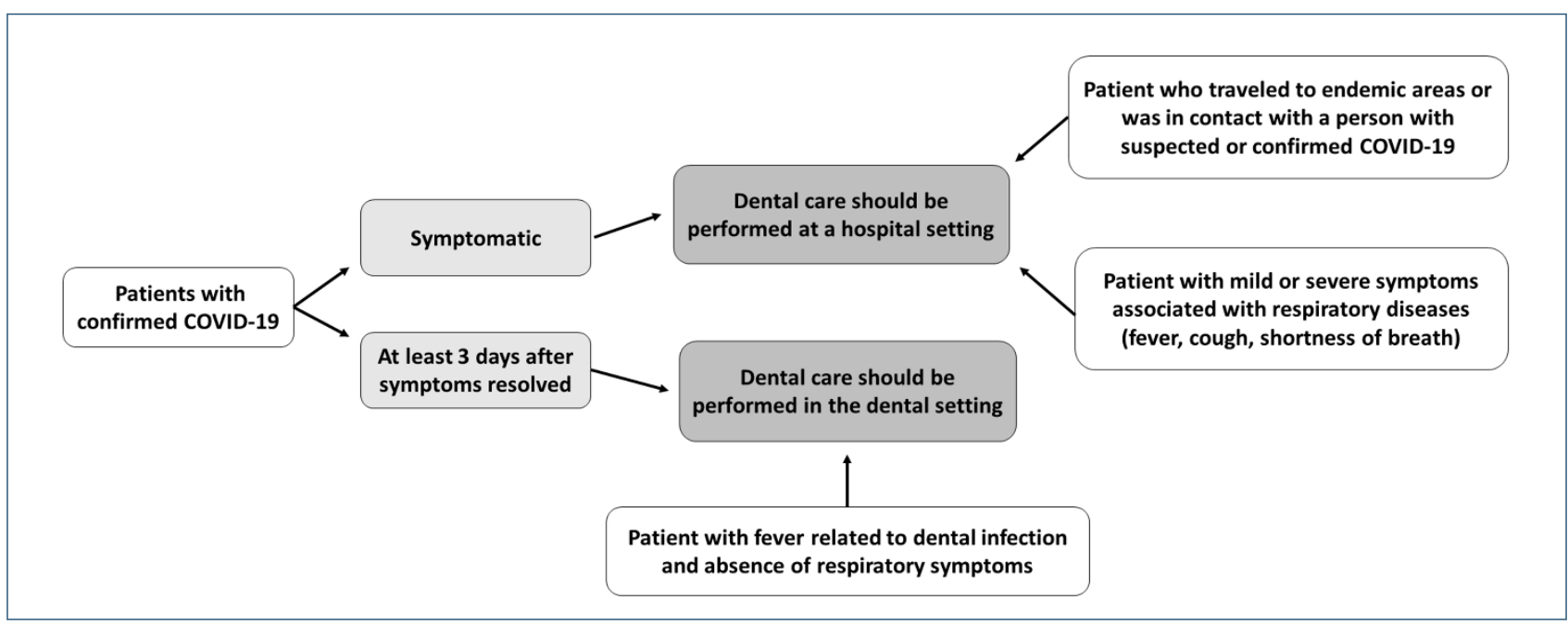

Figure 1: Algorithm to determine the location of the urgent or emergency dental procedure according to the patient's health status.

is different. Some have summarized and generalized measures, while others specify from protection of surfaces to the most suitable disinfectant solution. On the other hand, in addition to instruments, handpieces must be disinfected and autoclaved at each visit, a protocol that was previously recommended only in cases of surgery. In some reports and articles, it is also recommended ventilation of the environment between appointments when time can be variable, and therefore, there is no consensus between them.

Thus, there are many aspects of COVID-19 associated with dental practice, ranging from diminishing transmission to the identification of oral signs and symptoms. Thus, the dentist needs to understand and know how to adopt preventive measures as well as treat these manifestations ${ }^{10,11,39}$.

\section{Conclusions and future perspectives}

When analyzing the measures adopted by each country, there is a similarity regarding the instructions for screening and treatments to be performed as well as the recommended PPE. However, as a matter of comparison, some agencies are more incisive about cleaning and disinfecting the environment, while others have a concern about the procedure and instruments used during dental care, such as in Italy and China, respectively. Also, health agencies in the USA (ADA) and Brazil (ANVISA) focus on procedures that must be performed, exemplifying which urgencies and emergencies would be prioritized in the current pandemic scenario. Although with slight differences from one country to another, the challenges of the COVID-19 pandemic gave a new meaning to prevention in dental care so the place that promotes health does not become a transmission environment.

In view of all the information presented here, it is clear that the dental environment works as possible vector for the transmission of infectious diseases. Suddenly, with the arrival of COVID-19, the preventive measures previously adopted should be analyzed, reinforced, and adapted accordingly to this new scenario. However, what is observed is a lack of worldwide standardization on how dentists should proceed during and after the pandemic. This occurs because $\mathrm{WHO}$ has released very widespread reports for health practice within certain settings. For this problem to be resolved, it is essential that WHO assess all risks and prioritize biosecurity measures to reduce the risk of COVID-19 transmission in the dental environment. Until then, dentists follow their routine without an absolute truth, because every day there are new discoveries, and the adaptation process must be part of the new challenge in dental practice. We also reinforce and encourage all healthcare centers to perform intraoral examinations in patients suspected or affected by COVID-19 because these patients may have oral manifestations that can cause pain and discomfort.

\section{REFERENCES}

1. Meng L, Hua F, Bian Z. Coronavirus Disease 2019 (COVID-19): Emerging and Future Challenges for Dental and Oral Medicine. J Dent Res. 2020;99(5):481-7. https://doi.org/10.1177/0022034520914246
2. Rothan HA, Byrareddy SN. The epidemiology and pathogenesis of coronavirus disease (COVID-19) outbreak. J Autoimmun. 2020:102433.

https://doi.org/10.1016/j.jaut.2020.102433 
3. Yu F, Du L, Ojcius DM, Pan C, Jiang S. Measures for diagnosing and treating infections by a novel coronavirus responsible for a pneumonia outbreak originating in Wuhan, China. Microbes Infect. 2020;22(4):74-9

https://doi.org/10.1016/j.micinf.2020.01.003

4. World Health Organization (WHO). Coronavirus disease 2019 (COVID-19): situation report - 167. Available from: https:// www.who.int/docs/default-source/coronaviruse/situationreports/20200705-covid-19-sitrep-167.pdf?sfvrsn=17e7e3df_4

5. Pan X, Ojcius DM, Gao T, Li Z, Pan C, Pan C. Lessons learned from the 2019-nCoV epidemic on prevention of future infectious diseases. Microbes Infect. 2020;22(2):86-91. https://doi.org/10.1016/j.micinf.2020.02.004

6. Sun P, Lu X, Xu C, Sun W, Pan B. Understanding of COVID-19 based on current evidence. J Med Virol. 2020;92(6):548-51. https://doi.org/10.1002/jmv.25722

7. Adhikari SP, Meng S, Wu YJ, Mao YP, Ye RX, Wang QZ, et al. Epidemiology, causes, clinical manifestation and diagnosis, prevention and control of coronavirus disease (COVID-19) during the early outbreak period: a scoping review. Infect Dis Poverty. 2020;9(1):29 https://doi.org/10.1186/s40249-020-00646-x

8. Sabino-Silva R, Jardim ACG, Siqueira WL. Coronavirus COVID-19 impacts to dentistry and potential salivary diagnosis. Clin Oral Invest. 2020;24(4):1619-21. https://doi.org/10.1007/s00784-020-03248-x

9. Qu G, Li X, Hu L, Jiang G. An Imperative Need for Research on the Role of Environmental Factors in Transmission of Novel Coronavirus (COVID-19). Environ Sci Technol. 2020;54(7):3730-2. https://doi.org/10.1021/acs.est.0c01102

10. Carreras-Presas CM, Sánchez JA, López-Sánchez AF, Jané-Salas E, Pérez MLS. Oral vesiculobullous lesions associated with SARSCoV-2 infection. Oral Dis. 2020. https://doi.org/10.1111/odi.13382

11. Recalcati S. Cutaneous manifestations in COVID-19: a first perspective. J Eur Acad Dermatol Venereol. 2020;34(5):e212-3. https://doi.org/10.1111/jdv.16387

12. Gamio L. The Workers Who Face the Greatest Coronavirus Risk. Available from: https://www.nytimes.com/interactive/2020/03/15/ business/economy/coronavirus-worker-risk.html

13. Peng X, Xu X, Li Y, Cheng L, Zhou X, Ren B. Transmission routes of 2019-nCoV and controls in dental practice. Int J Oral Sci. 2020;12:9. https://doi.org/10.1038/s41368-020-0075-9

14. Wu F, Zhao S, Yu B, Chen YM, Wang W, Song ZG, et al. A new coronavirus associated with human respiratory disease in China. Nature. 2020;579:(7798):265-9.

https://doi.org/10.1038/s41586-020-2008-3

15. Zhou P, Yang XL, Wang XG, Hu B, Zhang L, Zhang W, et al. A pneumonia outbreak associated with a new coronavirus of probable bat origin. Nature. 2020;579:270-3. https://doi.org/10.1038/s41586-020-2012-7

16. Guo YR, Cao QD, Hong ZS, Tan YY, Chen SD, Jin HJ, et al. The origin, transmission and clinical therapies on coronavirus disease 2019 (COVID-19) outbreak - an update on the status. Mil Med Res. 2020;7(1):11.

https://doi.org/10.1186/s40779-020-00240-0

17. Chen $Y$, Guo $Y$, Pan $Y$, Zhao ZJ. Structure analysis of the receptor binding of 2019-nCoV. Biochem Biophys Res Commun. 2020;525:135-40. https://doi.org/10.1016/j.bbrc.2020.02.071
18. Xu H, Zhong L, Deng J, Peng J, Dan H, Zeng X, et al. High expression of ACE2 receptor of 2019-nCoV on the epithelial cells of oral mucosa. Int J Oral Sci. 2020;12:8. https://doi.org/10.1038/s41368-020-0074-x

19. Lai CC, Liu YH, Wang CY, Wang YH, Hsueh SC, Yen MY, et al. Asymptomatic carrier state, acute respiratory disease, and pneumonia due to severe acute respiratory syndrome coronavirus 2 (SARS-CoV-2): Facts and myths. J Microbiol Immunol Infect. 2020;53(3):404-12. https://doi.org/10.1016/j.jmii.2020.02.012

20. Kampf G, Todt D, Pfaender S, Steinmann E. Persistence of coronaviruses on inanimate surfaces and their inactivation with biocidal agents. J Hosp Infect. 2020;104(3):246-51. https://doi.org/10.1016/j.jhin.2020.01.022

21. Singhal T. A Review of Coronavirus Disease-2019 (COVID-19). Indian J Pediatr. 2020;87(4):281-6. https://doi.org/10.1007/s12098-020-03263-6

22. The Lancet. COVID-19: protecting health-care workers. Lancet. 2020;395:922 https://doi.org/10.1016/S0140-6736(20)30644-9

23. Ong SWX, Tan YK, Chia PY, Lee TH, Ng OT, Wong MSY, et al. Air, Surface Environmental, and Personal Protective Equipment Contamination by Severe Acute Respiratory Syndrome Coronavirus 2 (SARS-CoV-2) From a Symptomatic Patient. JAMA. 2020;323(16):1610-12. https://doi.org/10.1001/jama.2020.3227

24. Liu L, Wei Q, Alvarez X, Wang H, Du Y, Zhu H, et al. Epithelial Cells Lining Salivary Gland Ducts Are Early Target Cells of Severe Acute Respiratory Syndrome Coronavirus Infection in the Upper Respiratory Tracts of Rhesus Macaques. J Virol. 2011;85(8):4025-30. https://doi.org/10.1128/JVI.02292-10

25. Xu J, Li Y, Gan F, Du Y, Yao Y. Salivary glands: potential reservoirs for COVID-19 asymptomatic infection. J Dent Res. 2020;99(8):989. https://doi.org/10.1177/0022034520918518

26. Izzetti R, Nisi M, Gabriele M, Graziani F. COVID-19 Transmission in dental practice: brief review of preventive measures in Italy. J Dent Res. 2020;99(9):1030-8.

https://doi.org/10.1177/0022034520920580

27. World Health Organization (WHO). Rational use of personal protective equipment for coronavirus disease (COVID-19) and considerations during severe shortages. Available from: https:// apps.who.int/iris/bitstream/handle/10665/331695/WHO-2019nCov-IPC_PPE_use-2020.3-eng.pdf

28. Kohn WG, Collins AS, Cleveland JL, Harte JA, Eklund KJ, Malvitz DM. Guidelines for Infection Control in Dental Health-Care Settings - 2003. MMWR Recomm Rep. 2003;52(RR-17):1-61.

29. American Dental Association. ADA Interim Guidance for Minimizing Risk of COVID-19 transmission. Available from: https://www.ada. org/ /media/CPS/Files/COVID/ADA_COVID_Int_Guidance_Treat_ Pts.pdf

30. Silva AM, Silva Jr. DN, Lima KC. Orientações aos cirurgiõesdentistas para o atendimento odontológico no enfrentamento à COVID-19. Available from: https://ufrn.br/imprensa/noticias/35005/ departamento-de-odontologia-orienta-profissionais-sobrecuidados-durante-pandemia

31. Sociedade Brasileira de Periodontologia (SOBRAPE). Guia odontológico para atendimento durante a pandemia COVID-19. Available from: https://www.dfl.com.br/especiais/wp-content/ uploads/2020/04/guia_atendimento_pandemia.pdf 
32. Società Italiana di Parodontologia e Implantologia (SIP). Covid-2019 norme per l'attivita' odontoiatrica. Available from: https://www.sidp.it/media/taxtbu3.pdf

33. Itália. Ministero della Salute. Cinque regole da rispettare dal dentist. Available from: http://www.salute.gov.it/portale/ nuovocoronavirus/dettaglioNotizieNuovoCoronavirus. jsp?lingua $=$ italiano\&menu $=$ notizie $\& p=$ dalministero $\& i d=4231$

34. Odontoiatria33. Decalogo AIO su come affrontare il COVID-19 negli studi odontoiatrici. Available from: http://www.odontoiatria33. it/approfondimenti/19086/decalogo-aio-su-come-affrontare-ilcovid-19-negli-studi-odontoiatrici.html

35. Brasil. Conselho Federal de Odontologia (CFO). Nota técnica GVIMS/GGTES/ANVISA n 04/2020. Orientações para serviços de saúde: medidas de prevenção e controle que devem ser adotadas durante a assistência aos casos suspeitos ou confirmados de infecção pelo novo corona vírus (SARS-CoV-2). Available from: http://website.cfo.org.br/wp-content/uploads/2020/04/NotaTecnica-Anvisa-CFO-contra-covid-19.pdf
36. Ather A, Patel B, Ruparel NB, Diogenes A, Hargreaves KM Coronavirus Disease 19 (COVID-19): Implications for Clinical Dental Care. J Endod. 2020;46(5):584-95. https://doi.org/10.1016/j.joen.2020.03.008

37. American Dental Association (ADA). What Constitutes a Dental Emergency Available from: https://success.ada.org/ / media/CPS/Files/Open\%20Files/ADA_COVID19_Dental_ Emergency_DDS.pdf

38. American Dental Association (ADA). ADA Interim Guidance for Management of Emergency and Urgent Dental Care. Available from: https://www.ada.org/ /media/CPS/Files/COVID/ADA_Int_ Guidance_Mgmt_Emerg-Urg_Dental_COVID19

39. Odeh ND, Babkair H, Abu-Hammad S, Borzangy S, AbuHammad A, Abu-Hammad O. COVID-19: Present and Future Challenges for Dental Practice. Int J Environ Res Public Health. 2020;17(9):3151.

https://doi.org/10.3390/ijerph17093151 